Historic, Archive Document

Do not assume content reflects current scientific knowledge, policies, or practices. 
. 


\section{TREE PLANTING}

RETURN TO PONOLOPY

SECTION OF MOMENCTATURT:
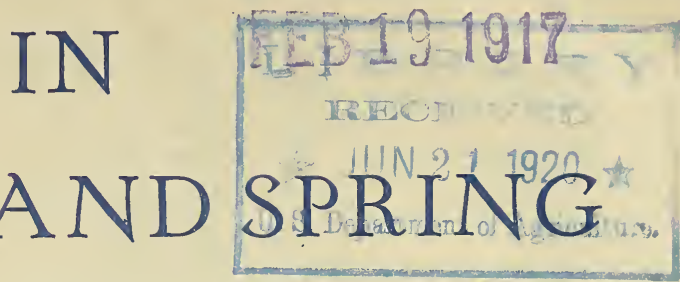

January and February are the great planting months in Texas and the Southwest. March has had largely increased plantings in recent years, and we have had to do considerable landscape planting even in April and as late as June for customers who had "put off."

\section{PLANT NOW IF YOU CAN}

Plant the glossy leaved evergreen Japan ligustrums, like those in front of our State capitol, for shades, screens and windbrakes. They live 400 years and never shed a leaf.

Plant elms, sycamores, locusts, ash, liveoaks, evergreens, flowering shrubs, roses and lilies. They give character, comfort and value to your home.

Plant peach trees, plums, apricots, apples, pears, figs, grapes, pecans and berries. The Smith peach is one that has never missed a crop.

The Ramsey Neverfail fig is a wonder first year.

The Haupt berries beat the world on quantity, quality and dollars.

We may trade trees for land in tracts of considerable size. Prefer western acreage or land with wild pecan trees on it.

We might top work large lots of pecan trees for a half interest in the nuts for a period of years.

Sales have been the heaviest the past fall that we have had in several years. Fortunately, we had a large stock to begin with, and shall be able all through the season to supply nearly anything wanted.

We shall always adhere to the policy of having none but satisfied customers.

Trees that die the first season after planting will be replaced at half of catalog price. This divides the responsibility and loss between our buyers and ourselves.

INFORMATION IS GLADLY GIVEN at all times, if we have it. Write us freely.

$$
\begin{gathered}
\text { THE AUSTIN NURSERY } \\
\text { A"'. T. RAMSEY \& SON } \\
\text { Austin, Texas }
\end{gathered}
$$




\section{THE AUSTIN NURSERY}

F. T. RAMSEY \& SON

Austin, Texas, December 30, 1916.

Owing to the unusually heavy demand for nursely stock this season, we can now offer only the following varieties in trees and plants named: PEACH. These in all grades:

$\begin{array}{lll}\text { Augbert } & \text { Alexander } & \text { Matthews Beauty } \\ \text { Augusta } & \text { Bells October } & \text { Miss May } \\ \text { Best June } & \text { Champion } & \text { Mixon Cling } \\ \text { Chilow } & \text { Christabel } & \text { Mixon Free } \\ \text { Ernst } & \text { Craddiebel } & \text { Onderdonk } \\ \text { Governor Lanham } & \text { Crawford Early } & \text { Pallas } \\ \text { Hobson } & \text { Crawford Late } & \text { Rivers } \\ \text { Lane } & \text { Crosby } & \text { Rupley } \\ \text { Octoberta } & \text { Elberta } & \text { Salway } \\ \text { Ramsey Late } & \text { Equinox } & \text { Snow Cling } \\ \text { Smith } & \text { Family Favorite } & \text { Stanford } \\ \text { Smith Indian } & \text { Honey } & \text { Stump World } \\ \text { Surties } & \text { Imperial } & \text { Sylphide } \\ \text { Taylor } & \text { Indianbel } & \text { Thurber } \\ \text { Weaver } & \text { Indian Cling } & \text { Victor } \\ \text { Wheeler } & \text { Japan Dwarf } & \text { Seedlings }\end{array}$

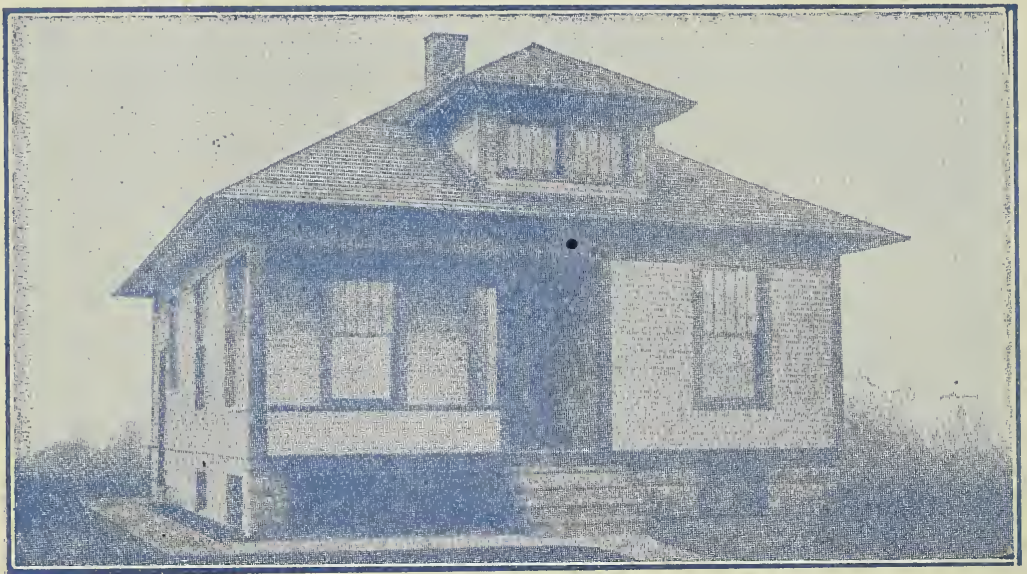

The plain little cottage above is bare. With a small amount invested in vines, trees, evergreens and flowering shrubs, it could be made beautiful, home-like and worth many times more in dollars and cents.

The following in 2-3-foot grade only:

$\begin{array}{lll}\text { Leona } & \text { Chinese Cling } & \text { Rogers } \\ \text { Cablers Indian } & \text { Jackson } & \text { Stinson } \\ \text { Carman } & \text { Lee } & \text { Triumph } \\ & \text { Mamie Ross } & \end{array}$

PLUM. In all grades: Abundance, Burbank, Botan, Wickson.

We can now offer these in 2-3-foot trees mainly, with only a few larger for the balance of this season:

$\begin{array}{ll}\text { Advance } & \text { Happiness } \\ \text { Bilona } & \text { MicCartney } \\ \text { Biola } & \text { Oxheart } \\ \text { Doris } & \text { Santa Rosa } \\ \text { Gold } & \text { Sultan } \\ \text { Gonzales } & \text { Tanwick }\end{array}$

Wonder

America

Arkansas Lombard

Bartlett

Clifford

Eagle 
El Paso

Excelsior

Indian Chief
Nona

Ohio Prolific

Pools Pride
Robinson

Wild Goose

Wooten

APPLE. In all grades as follows:

Becker

Arkansas Black

Astrachan

Ben Davis

Early Harvest

\section{Gano}

Jonathan

M. B. Twig

Mo. Pippin

Shockley
Summer Queen

Wine Sap

Yellow Transparent

Transcendent

We have in 2-3-foot only:

Bismarck

Helm

Talbot

Red June

The cut below shows an Austin residence that is noted for the beauty of its grounds, which are a framework and setting for the house built of brick and mortar.

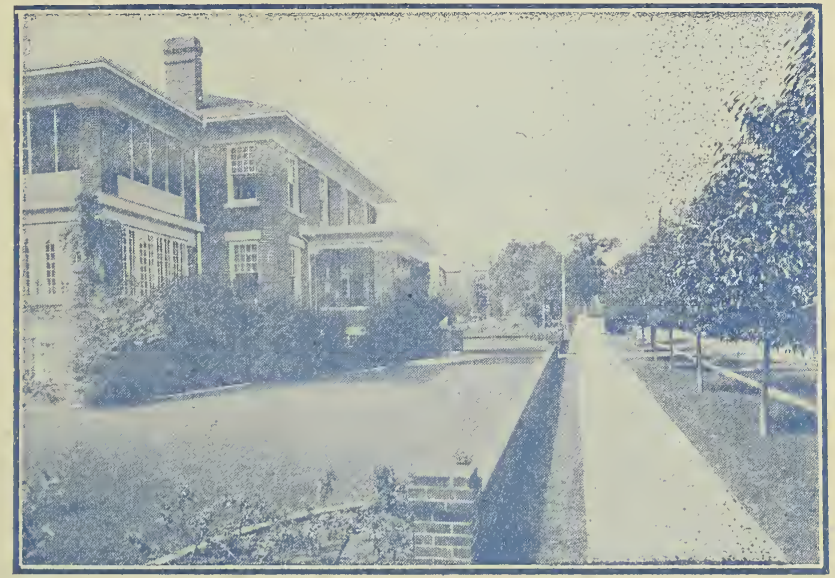

MAKE YOUR HOME GROUNDS BEAUTHFUL

ROSES.

American Beauty

Baby Rambler

Baltimore Belle

Bonsilene

Bridesmaid

Burbank

Cloth of Gold

Crimson Rambler

Dorothy Perkins

Empress of China

Etoile d'Lyon

General Jacqueminot

Helen Gould

Helen Gould Clb

John Hopper
Kaiserina

Kaiserina Clb

Killarney

La France Pink

La France White

McArthur

Madam Mason

M. C. Testout

Malmaison Pink

Malmaison White

Mam. Cochet

Marechal Neil

Moss Pink

Moss White

Martha Washington
Meteor

Meteor Clb

Papa Gontier

Paul Neyron

Paul Neyron Clb

Pearl of Garden

Queen Scarlet

R. M. Henrietta

Safrano

Seven Sisters

Solfatere

Tiplitz

Vicks Caprice

W. A. Richardson

BERRIES. All kinds except Jordan and Rogers.

EVERGREENS. All kinds except Ramsey Hybrid. 


\section{MAKE YOUR \\ HOME GROUNDS \\ BEAUTIFUL}

Never before have people been so interested in improving the appearances of their grounds and yards, in keeping with the interior of their homes, as they are now.

This is proper. But few persons see the inside of your home, but every passer-by sees the exterior and passes judgment upon the character of its owners thereby.

It is a civic duty to have beautiful surroundings for your home, due yourself, your family, and your neighbors.

We have done landscape work in nearly all parts of Texas and know the requirements of every section. We can make you the plan for proper planting, and execute the work, if desired.

For real satisfaction, we believe we can really give the most for the amount invested.

There are ten large contracts closed for landscape work now (January 2, 1917) in Texas, New Mexico and Arkansas. We hope to be able to answer all calls made on us. Page 26 of catalog gives details in regard to landscape work.

\section{THE AUSTIN NURSERY}

Nistablished 1875

\section{F. T. RAMSEY \& SON}

Austin, Texas

420 Acres

We pay express in Texas on $\$ 3.00$ orders, and on $\$ 10.000$ orders outside of Texas. 